\title{
Article
}

\section{Corporate-NGO Partnerships through Sustainability Labeling Schemes: Motives and Risks}

\author{
Sylvaine Poret ${ }^{1,2 *}$ \\ 1 INRA ALISS UR1303, F-94200 Ivry-sur-Seine, France \\ 2 Ecole Polytechnique CREST, F-91128 Palaiseau, France \\ * Correspondence: sylvaine.poret@inra.fr
}

\begin{abstract}
This article analyzes the emergence of partnerships between corporations and nongovernmental organizations (NGOs) through voluntary product labeling schemes. The economics, management, and business literatures are reviewed to highlight cross-checking, consistencies, and complementarities among these disciplines. The objective is to identify and analyze the motives, risks, and joint benefits of partnering via voluntary product labeling, using examples from the agri-food sector. This study is an attempt to offer a framework of corporate-NGO partnerships by showing that the drivers and risks of each partner merge because each takes a step into the sphere of the other. The main risks - namely, a loss of profitability, credibility and legitimacy - are related to the financial and existential dependency and the asymmetric information between the partners in favor of corporations, inducing an "NGO-capture" risk.
\end{abstract}

Keywords: Corporate Social Responsibility; Cross-Sector Alliance; Firm Strategies; Nongovernmental Organizations; Sustainability Labels

\section{Introduction}

For the last thirty years, new constraints have been imposed on companies, including the impact of their activities on climate and local communities. Corporate social responsibility (CSR) is now a necessity for corporations. The World Bank defines CSR as "the commitment of businesses to behave ethically and to contribute to sustainable economic development by working with all relevant stakeholders to improve their lives in ways that are good for business, the sustainable development agenda, and society at large" (see the World Bank's website). Faced with the questioning of corporate self-regulation perceived as greenwashing, a new approach has emerged: coregulation and multistakeholder initiatives [1]. The coregulation method involves civil regulation, in which nongovernmental organizations (NGOs) play a key role. The desire to counterbalance the negative reputational impact of self-regulation instruments is a driver of companies' partnerships with NGOs. In this sense, the activities of NGOs in corporate-NGO partnerships appear to result from regulatory failures since NGOs are the institutions in which citizens have the most confidence in almost all countries in Europe, America and Asia - leading companies, governments, and the media for many years [2]. NGOs and firms exert "private political authority" as nonstate actors that can exert legitimate authority at national and international levels in the provision of public goods [3].

This research focuses on a particular type of partnership, voluntary product labeling schemes, that can be viewed as corporate social innovation [4] and falls under "strategic CSR" as a socially responsible approach to reinforcing a firm's market position and increasing its long-term profits [5]. The specificity of a corporate-NGO partnership in product labeling schemes is that the names of the partners are explicitly displayed through products as the object of the partnership. In this case, the firm is a channel for the expression of consumer values, which Bénabou and Tirole call "delegated philanthropy" [6], and it helps consumers express their philanthropic desires through their economic decisions. Voluntary product labeling schemes involve a tripartite standards regime: the establishment of criteria or standards, the creation of evaluation mechanisms with independent 
enforcement or certification, and the recognition of a control party by an authoritative body or through accreditation $[7,8]$. Therefore, voluntary product labeling schemes are equivalent to Type I (ISO 14024) ISO's classification of labels, which are based on a set of minimal criteria defined by private or public environmental labeling programs and are controlled by third-party certifiers [9]. Type II labels are self-declared claims adopted by manufacturers or retailers, and type III labels consist of quantified product information based on life cycle impacts [9].

Labels are a visible means of signaling to consumers that products meet required standards. In this context, an increasing number of NGOs have developed their own third-party certifications or standards with labels to distinguish sustainability practices from conventional ones. In this way, NGOs often act as standard setters. According to the 2010 Global Ecolabel Monitor, most ecolabels (58\%) were operated by nonprofit organizations, $18 \%$ by for-profit organizations, $8 \%$ by governments, and the remainder by other actors [10].

This study is therefore limited to NGOs that act as sustainability standard setters for the common good and at a national or international level, such as Fairtrade Labelling Organizations (FLO) International (Fairtrade label), Rainforest Alliance, the Marine Stewardship Council, or Forest Stewardship Council. It is important to understand why and how firms choose to work with NGOs rather than standardization offices and agencies or consulting firms. With voluntary product labeling schemes, corporate-NGO partnerships are no longer unilateral, limited, and based purely on a financial transaction, because, with these tools, the two organizations combine their name and then share risks. Together, these two very different types of organizations, MNCs and NGOs, play an increasingly important role in providing public goods - the former because they have resources, global reach, and levers of action, and the latter because they have legitimacy, knowledge, and expertise. The choice of an NGO, that is, of a label, for a firm as partner and the acceptance by the NGO of the firm's proposition then become strategic variables for both partners. Therefore, the question is, does the partnership truly work for the benefit of both partners?

The number of corporate-NGO partnerships has increased significantly, and these partnerships are viewed by academics and practitioners as an unavoidable and powerful means to implement CSR [11-16]. However, the ways in which these partnerships are implemented are not completely understood [17]. Moreover, the methods of implementing such partnerships are highly related to the partners' motives. To develop successful business-NGO partnerships, it is important to understand the worldviews, interests, and risks of each party.

This paper aims to analyze why and how corporate-NGO partnerships in voluntary product labeling schemes are implemented by cross-referencing analyses from the economics, management, and business literatures on this topic to highlight cross-checking, consistencies, and complementary features. The original contribution of this approach is that the analysis is conducted from a dual perspective in terms of concepts and the literature: an economic perspective and a management and business perspective. With this analytical framework, the paper identifies and analyzes the motives, risks, and joint benefits of partnering via voluntary product labeling using examples from the agri-food sector, which is one of the most important economic and political areas in the world, with key implications for sustainability such as the fulfillment of human needs, the support of employment and economic growth, and the impact on the natural environment. The task of the paper is thus to add value to our understanding of the drivers and dynamics of this category of cross-sector partnering collaborations.

The academic economics literature includes very few works concerning CSR, and the issue of partnerships is never quite addressed. The authors of [18] and [19] review the economics of CSR from a broader perspective by analyzing CSR as an answer to four types of market failures: public goods and externalities, imperfect competition, incomplete contracts, and innovation and resources access. The authors of [20] define CSR from an economic perspective having developed a comprehensive taxonomy that connects formerly disparate approaches to the subject. Finally, the authors of [21] 
review the literature on CSR, considering social preferences and issues such as CSR and firm size and the influence of different corporate governance systems on CSR.

Contrary to the economics literature, the CSR field in the management and business literatures is vast and heterogeneous, with a proliferation of theories, approaches, and terminologies [22,23]. One such theory is stakeholder theory, which emphasizes the need for companies to respond to a broader range of stakeholders. Most of the academic literature on business-NGO relations is positioned in a business case orientation, that is, benefits that can be taken away by companies by better considering the expectations of stakeholders [24,25]. Moreover, theories of risk management and organizational learning stress the importance of multistakeholder dialogue and NGO-business partnerships as ways by which firms can acquire knowledge. Furthermore, a growing part of the business and management literature analyzes business-NGO partnerships and their role in affecting CSR, although dyadic antagonism and the pressure response model appear to be the most analyzed issues [14,25].

This article proceeds as follows. First, I present partners' motives for engaging in a voluntary product labeling scheme. Second, some elements of the partnership implementation process are analyzed in greater depth. Afterwards, I analyze the related risks for both partners. Finally, I conclude by summarizing the results and offering suggestions for further research.

\section{Motives of partnerships}

A company may engage in CSR activities for various reasons, namely, philanthropy, CSR in a stakeholder approach, strategic CSR, and defensive CSR $[5,20,26]$. However, it is also important to take NGOs' motivations into account and to consider them as actors in the relationship rather than merely as objects [24], especially in the context of voluntary product labeling schemes that combine the names or the brands of both partners.

\subsection{Information}

The increasing role of NGOs in CSR activities is explained by the information asymmetry between firms and citizens/consumers [27]. Information asymmetry problems are related to the difficulty of obtaining information about firms' behaviors, operating practices, and sustainability quality of their products. Sustainable goods have attributes that consumers cannot evaluate even when they use them. Consumers cannot inspect particular produce items and, simply by purchasing and using them, determine whether they were grown organically, whether they are the product of biotechnology, or whether a firm harms the environment or builds strong relationships with local communities. Such products are called credence goods [28,29]. There are two other broad classes of products: search goods, which have characteristics that are discoverable through inspection prior to purchase and consumption, and experience goods, which have characteristics that are revealed only through consumption. The presence of credence attributes can create three phenomena: free riding [30], moral hazard [31], and adverse selection [32]. First, greenwashing can be compared to free-riding behavior, as firms may lie about their CSR activities, in particular through self-declared claims (ISO type II labels), and they may receive the benefits related to CSR attributes created by others [27]. Second, this problem can also be compared to moral hazard, which arises when an agent's behavior is not appropriate. In a purchase contract, a firm may provide misleading information about its CSR activities, always through a self-declared label, and customers are then affected because they do not receive the good for which they paid. Third, the adverse selection problem is due to the impossibility of verifying the quality of a product or a corporation's behavior. This leads to oversupply of "low-quality" goods in the market in the classic "lemons" effect [32].

Partnerships can solve these problems with respect to the intangible aspects of business because third-party certification and monitoring improve communication about sustainability issues. Therefore, contractual safeguards, certification, and labels are mechanisms designed to address problems derived from the presence of credence attributes and the consequent information asymmetry. Indeed, quality 
signals, especially labels, can transform credence attributes into search attributes, whose quality is readily observable prior to purchase [33].

In this context, NGOs represent an important source of information for citizens/consumers who value the behavior of firms and the quality of products. NGOs may affect the information that is available to consumers for their purchasing decisions through two main channels: cooperation and confrontation. These channels are described within the terminology of Lyon as "Good Cop/Bad Cop" [34]. The so-called "bad cops" or polarizing NGOs, such as Greenpeace, tend to achieve change by disrupting the status quo through confrontation [35]. Empirical studies of boycotts are inconclusive about their effectiveness [36]. Free riding may be a cause of boycott failures: since boycotting is costly in terms of consumer utility, any consumer has an incentive to free ride, that is, to not participate in the boycott while hoping that it succeeds. Vogel argues that even publicized protests have an insignificant financial impact [37]. Moreover, some NGOs and environmental groups are uncomfortable with boycotts since this practice could punish small producers and vulnerable populations, especially in the agri-food sector in which many globally traded commodities, such as coffee and cocoa, are produced by smallholder farmers and poor workers in developing countries.

The inefficiency of boycotts and their unexpected repercussions may first have induced a new form of ethical or political consumerism, the buycott. In buycotting, consumers make use of product information and labeling to select products or corporations with specific practices and qualities that are considered ethical or sustainable. Second, this may also explain the change in interactions between corporations and NGOs. Indeed, "Good cops" or integrating NGOs, such as the WWF, aim to promote their goals through constructive partnerships with businesses, governments, and other civil society organizations [38].

In the context of the globalization of exchanges and the transnationalization of companies, NGOs are in better position than certifying agencies or governments to provide standards, certifications, and labels because, similar to MNCs, most NGOs act at an international level. In addition, the creation of a label with a tripartite standards regime represents a significant investment in terms of time, knowledge acquisition, expertise, and recognition. NGOs engaged in this process become a source of credible information due to their accreditation system supporting the label quality assertion. Indeed, most initiatives provide guarantees and prove their ability to carry out inspections according to standards criteria through an accreditation: the ISO guide 65 regulates work methods (procedures, instructions) for certification bodies no matter what their domain. Finally, through their external intervention, by developing a wide range of more or less strict, nondiscretionary regional, national, or international standards and by delivering credible information, NGOs allow firms to credibly signal that their products possess sustainable attributes.

\subsection{Legitimacy}

Why are NGOs legitimate actors in disclosing relevant information about corporations? Legitimacy is "a generalized perception or assumption that the actions of an entity are desirable, proper, or appropriate within some socially constructed system of norms, values, beliefs and definition" [39]. Baur and Palazzo note that the reference to the notion of a public good or common good in NGOs' claims induces legitimacy per se [3].

Stakeholder theory argues for the existence of a contract between the firm and society. In the case of a breach of such a contract, the firm loses its legitimacy. The authors of [40] note that "the notion of license to operate derives from the fact that every company needs tacit or explicit permission from governments, communities, and numerous other stakeholders to do business". Therefore, companies must maintain their stakeholders' authorization to operate and must therefore address their stakeholders. A stakeholder is defined as "any group or individual who can affect or is affected by the achievement of the organization's objectives", including employees, customers, consumers, suppliers, investors, communities, governmental bodies, political groups, competitors, trade associations, trade unions, and NGOs [41]. By definition, NGOs basically have a rightful place as a stakeholder. Moreover, 
NGOs spearhead CSR for a number of environmental or social purposes through the information or instruments they provide. The authors of [42] show that such NGOs are recognized by other stakeholders as the primary actors in the introduction and development of CSR and that corporations perceive NGOs as one of their primary stakeholders. NGOs act as a representative of people, the environment, or future generations, that is, as a representative of any entity affected by companies' activities. For that reason, NGOs are a bridge between corporations and their other stakeholders [43], especially through the flow of information that NGOs create among these entities and the trust that they inspire. Thus, NGOs become the suppliers of legitimacy for firms, and engagement between NGOs and corporations can serve as a risk management tool, i.e., a reputational insurance policy, against attacks on their products or brands.

Nevertheless, it seems that some highly professional and business-oriented NGOs have to reinforce their legitimacy among their potential business partners, corporations and consumers, and other NGOs. For Schepers [44], global governance mechanisms must possess both moral and pragmatic legitimacy, as the latter is vital to their success. He adds that "the achievement and maintenance of such legitimacies, however, is a constant struggle for such organizations" (p. 293). This is the case for the FLO in the fair trade movement. In 2003, the FLO split into two distinct organizations. While the FLO-I's mission is to develop and review fair trade standards with the Fairtrade label, FLO-Cert as a certifying body ensures that producers and traders comply with these standards. By creating a tripartite standards regime, the FLO has gained legitimacy in the business sphere. Conversely, fair trade movement initiators, such as Alternative Trade Organizations, which are characterized by relational governance in which exchange relations are coordinated through norms of trust, obligation, partnership, and shared expectations, believe that the FLO has lost its legitimacy by undermining the original intent of fair trade [45].

\subsection{Profitability and mission}

Firms may secure their supply chain and use CSR as a source of competitive advantage by reducing costs. Indeed, for many MNCs, a large proportion of their agricultural raw materials are purchased on global commodity markets where there is little control over source, quality, and growing methods. MNCs thus risk losing reputation because of a decrease in their product quality. By developing sustainable relations with suppliers through standards, firms can secure their sources of supply through a long-term partnership, maintain quality standards along the supply chain, and optimize purchase costs since producers and other suppliers will therefore feel more secure. For instance, in the Unilever-Rainforest Alliance partnership on Lipton tea, the created certification system increases the amount of direct transactions between Unilever and farmers, which allows the firm to carry out fewer purchases on the spot market. Finally, the certification scheme boils down to cutting out some intermediaries, which reduces the sourcing cost [45]. Thus, standards can result in more efficient supply chain management along with the environmental and social benefits generated. This is a good example of synergistic collaborative value.

NGOs' resources, such as legitimacy, expertise, and sources of information, are used to achieve certain objectives. It is well known that NGOs operate under the guiding principle of "mission, mission, and more mission" [46]. Mission statements, which can be viewed as a set of concepts toward which an NGO can direct funds, can be used as a strategic instrument to attract donors or consumers and produce a social impact [47]. The intensity with which an NGO addresses issues, such as the stringency of a standard, is also a strategic variable. Moreover, the choice of issues and the level of requirements are sources of differentiation among NGOs [48,49]. A substantial body of literature on the economics of labels compares standard levels by the type of standard-setting organization: government, NGO, or industry [50-53]. In this literature, the objective of the NGO is to maximize social or environmental quality or to minimize a specific threat, which is usually related to an externality or a public good in the sense that NGOs are prosocially motivated. However, in the vein of the literature on the donation market, the authors of $[48,49]$ assume that NGOs are concerned only with their own programs, that is, 
the social output they individually produce. In this sense, NGOs act on behalf of the common good and may have particular interests [3]. Given an NGO's mission statement, the rise of societal problems motivates NGOs to collaborate with corporations. Indeed, a partnership is a way to sensitize corporate clientele to the NGO's cause and mission.

The second principle of NGOs is "no money, no mission" [46]. The increasing scarcity of public funds and the increasing number of NGOs force these organizations to find new sources of funding. Because firms are institutions with relatively easier access to financial resources, NGOs are motivated to establish alliances with corporations.

\subsection{Differentiation and visibility}

CSR activities can create a competitive advantage for firms through vertical or horizontal product differentiation. In this context, a firm's supplied product is distinguished from other products by its quality or by specific characteristics or attributes, which might also allow the firm to sell the product at a higher price, create a niche market, or see its market shares grow through the first-mover advantage in the market. Indeed, consumers generally take into consideration firms' CSR activities when making purchase decisions, and this consideration leads to either an increase in willingness to pay (WTP) a premium for the product or an increase in purchase intention [5,54].

With the leading tea brand Lipton, Unilever adopted this last strategy with the conversion of an existing leading brand. In May 2007, Unilever, the world's largest tea company, became the first company to commit to sourcing all of its tea in a sustainable manner, employing the Rainforest Alliance to create standards and to use its label [45]. At the end of 2015, all the tea for Lipton tea bags was sourced from Rainforest Alliance-certified farms, and Unilever is committed to sustainably sourcing $100 \%$ of its tea by 2020 . This first-mover strategy was actually followed by some competitors, as a few years after the launch of this new labeling scheme, many of Unilever's major competitors, such as Tetley, Twinings, and Pickwick, made similar commitments with different NGOs, including Rainforest Alliance, UTZ certified, and Fairtrade (FLO), to certify their products.

For NGOs, a motivation for collaboration with corporations is the increase in social problems. Indeed, a partnership is a way to sensitize corporate clientele to an NGO's cause. A positive consequence of such partnerships is an increase in visibility that may enhance the NGO's notoriety: an association with a firm with a strategic position in the market is one way for an NGO to strengthen its reputation, public image and political influence [12,55]. For instance, the concept of fair trade experienced an impressive expansion following the launch of the Max Havelaar label (Fairtrade), which is awarded to brand-name products or private label products sold in large retail stores $[45,56]$. Another example is the partnership between Unilever and Rainforest Alliance, which allowed the American NGO to make itself known in Europe and to develop its activities.

The use of credible labels allows firms to signal the presence of sustainable attributes and, in doing so, to create the potential for premiums based on that signal. On the demand side, a large number of studies address consumer WTP for environmentally friendly foods and for social sustainability attributes, and their determinants. In a meta-analysis conducted on eighty studies that estimate WTP for a large number of product categories, the authors of [57] show that certification increases WTP for socially responsible products by $7 \%$ on average and that WTP is greater for products for which the socially responsible element benefits humans (e.g., labor practices) compared to those that benefit the environment. In addition, several studies using controlled experimental frameworks show that consumers are willing to pay (slightly) higher prices to buy a product that implies a donation to an NGO [58-60].

\section{Processes of the partnership}

The development of a corporate-NGO partnership has been well analyzed in the management literature by using a chronological sequence of the evolution of such a partnership at three different stages: formation, implementation, and outcome [12,61-64]. In the context of partnerships through 
sustainability labeling schemes, the induced association between the firm's brand and the NGO's logo raises several more specific questions: the purpose of the partnership, the level of involvement of partners, and the related corporation's brand management.

\subsection{Purpose}

Despite numerous international reports, a universally accepted and understood definition for sustainability is lacking. A crucial question concerns how to translate sustainability issues into a firm's social responsibility and into a product having a sustainability attribute [7]. Indeed, in practice, sustainability induces a multiplicity of criteria that can be integrated into products, production processes, supply chain actions, and trade relations [65].

In terms of topics, one can distinguish sustainability issues that identify relevant "ideals", such as recycling, from sustainability issues that avoid "ills", such as dolphin protection [7]: agreeing on the ills to be avoided (e.g., poverty) is often easier for a heterogeneous society than agreeing on the ideals to be achieved (e.g., the ideal income distribution). Differences also arise with respect to generic issues (e.g., fair trade), sector-specific labels (e.g., dolphin protection), and firm- or value-chain-specific problems. Generic labels are appropriate for products for which standards can be easily defined and for which there are no controversial political issues [7]. However, concepts such as sustainability, ethics, and fairness are ambiguous and controversial, and clearly defining the problem is essential for the success of a partnership. For instance, fair trade is a trading strategy that guarantees producers a fair price for their products. What does a "fair price" mean for a product grown by producers living in countries with different living conditions and with different methods?

To target a relevant issue, the strategic approach is not only to identify a particular set of societal issues that the firm is the best equipped to help resolve and from which it can gain the greatest competitive benefit but also to sort social issues into three categories - generic social issues, value chain impacts, and the social dimensions of the competitive context - for each of its activities and locations with respect to the principle of shared value [40]. This is a good way to identify the points of intersection between activities and societal problems with respect to the principle of shared value and to find consistency between a relevant societal issue to manage and a product offered by the firm. On this basis, the firm can target the relevant NGO and specify what the NGO can provide in terms of technical support, skills, and networks.

To meet this demand, many NGOs reorient and expand their action by using their knowledge through activities such as training, information sharing, consultancy or advice for companies; so they can ultimately supply turnkey goods and services such as labels. The more established and larger NGOs employ policy analysts, lawyers and scientists, with skills weakly present in the business world. For instance, the internationally recognized fair trade organization, the FLO (Fairtrade label), defines itself as a worldwide network of producers, trading companies, and national labeling initiatives that sets fair trade standards and that provides fair trade certification and trade auditing. Due to its extensive practical field experience, the FLO provides access to a network of producers or contact facilitation to create a specific network of suppliers.

\subsection{Commitment}

The commitment of partners in corporate-NGO partnerships can vary. The "Collaboration Continuum" by [66] describes how such collaboration evolves over time, depending on a firm's stage of CSR and the firm's motives, as described above. At the philanthropic stage, firms may consider NGOs to be recipients of charitable activities; thus, the interaction between parties may be fairly minimal and unilateral, flowing from the company to the NGO [16]. Moving on to the transactional stage, firms begin to increase the intensity of their interaction with NGOs through resource-exchange activities, such as sponsorships, cause-related marketing, licensing agreements, and certifications. Some collaborations may evolve to the integrative stage, in which corporations move beyond bottom-line considerations to consider how to balance those considerations with social 
and ecological concerns. The final stage, transformational or transformative engagement, refers to the situation in which firms and NGOs begin to merge their missions, people, and activities. Firms that respond at this level not only embed sustainability in every aspect of their operations and tie it into their strategic objectives but also are interested in managing and integrating stakeholder expectations at each level of their activities.

For instance, since its creation, Ben and Jerry's, an American ice cream company, has donated $7.5 \%$ of its annual pretax profits to charitable causes through its foundation. This charitable activity is part of its business model, and it has contributed to its reputation. In 2006, Ben and Jerry's adopted the Fairtrade label in Europe and the United States, and since January 2015, all sugar, cocoa, vanilla, coffee and bananas in Ben and Jerry's products have been certified by the FLO. According to the company's website, the company mission statement includes three parts, namely, economic, product, and social, with the aim of "being a global company and at the same time being a progressive business that is connected to people and communities".

A partnership with a labeling scheme represents the integrative stage of the collaboration continuum, where the value of the collaboration itself becomes critical to both parties with high synergies [66]. Logically, close collaborations with direct and ongoing engagement are more likely to arise with companies that are more advanced in their CSR policy [67].

In practice, an MNC has several options for driving a sustainability program, depending on the level of the CSR process at which the NGO intervenes and the level of the partners' involvement. First, the relationship between an NGO and a firm may be limited to a communication campaign, which can be viewed as a cobranding operation. The WWF has established a significant cobranding program with its Panda logo. Many firms, such as Sony for televisions and Fellowes for recycled paper, cobrand with the WWF to obtain a more environmentally friendly image and to enhance consumers' trust in their brand or product and loyalty. Products must meet environmental and social criteria, and the WWF requests an independent certification of products, such as WWF-accepted labels and certification systems.

Second, an NGO may act as a monitoring agency to control the code of conduct implemented by a firm. The Fair Labor Association (FLA), a nonprofit network of universities, NGOs, and companies, was created in 1999 to establish independent monitoring and a code of conduct in firms, including a minimum age and a maximum-hour work week. The FLA conducts independent and unannounced audits of factories that are used by FLA affiliates to evaluate companies' compliance with all code elements and to verify companies' internal compliance efforts. For instance, Nike Inc.'s compliance program is accredited by the FLA.

The third option for a company is the creation of a partnership with an NGO to develop a code of conduct or a specific standard. In 2003, Nestlé, with its Nespresso brand, the worldwide leader in high-quality premium portioned coffee, worked with the NGO Rainforest Alliance to improve its performance in terms of quality and sustainability by developing its own standards: the Nespresso AAA Sustainable Quality Coffee Programme. The Rainforest Alliance logo, a green frog, does not appear on the packaging, and it is not used in communications.

Finally, a firm may choose an existing well-established label that is owned by an NGO. In this context, the firm must fully comply with the standards that are defined by the NGO. In 2006, Unilever chose this strategy for its Ben and Jerry's brand and adopted the Fairtrade label in Europe and the United States.

\subsection{Brand strategies}

A CSR product-oriented action must fit into a brand strategy. Indeed, a firm may invest in its brand to render the relevant sustainability issues consistent with its other messaging to consumers. However, four different strategies have been identified to implement a sustainability program through a brand by selling labeled products [45]. These choices can be viewed as make-or-buy decisions: creating a new sustainable brand or buying it, developing a new standard or using an existing one. 
The first strategy that comes to mind is to create a new brand that is identified as sustainable, as an alternative through which an international company can implement a CSR approach. In 2006, Danone created Stonyfield Europe and marketed a new brand of organic yogurts in France: "Les deux vaches". Stonyfield Farm, the US partner that holds $20 \%$ of Stonyfield Europe, gives $10 \%$ of its profits to environmental causes. However, creating a new brand by a firm may be expensive and time consuming, and finally this strategy is riskier than the extension of an existing strong brand.

Therefore, the second strategy of extending a firm's product range in the context of a well-established brand is more common. After years of resistance, face attacks from activists and increasing consumer demand for sustainable products, in 2006, the Procter \& Gamble Company, under its brand Millstone, began selling a line of fair trade coffee certified by TransFair USA.

The third strategy is the acquisition of a brand with a strong commitment to social responsibility. Indeed, a firm can buy out an existing firm that has distinguished itself from other firms through a long-term commitment to social responsibility, with CSR being a part of its corporate strategy and business identity [37]. Unilever chose such a strategy by buying out Ben and Jerry's in 2000. The fourth strategy is the conversion of an exciting leading brand. In 2009, Cadbury announced that it was going to move to FairTrade sourcing for Dairy Milk, the most popular chocolate bar with 300 million bars sold per year in the UK and Ireland. It became the first mass-market chocolate brand to adopt the Fairtrade label.

The success of a brand depends on a firm's ability to select a brand meaning, to transform the meaning into an image, and to maintain the image over time. For the success of a corporate-NGO partnership, a good combination between the two partners in terms of meaning and image must be established without requiring sudden changes. Moreover, a brand with multiple concepts may be less effective at establishing a position, as consumers may then have more difficulty identifying the brand's basic meaning. The same argument can be applied to multiple labels on one product. Indeed, during the last decade, hundreds of labels aiming to guarantee various process qualities (e.g., organic, fair trade, and carbon footprint) have flooded the market. The accumulation of information creates a "halo" effect, whereby consumers experience a feeling for a product based on a few pieces of information and then use this feeling to infer the value of some other attribute [68]. For example, an experimental study shows that consumers' WTP for chocolate is the same regardless of whether a product has an organic label, a fair trade label, or both, even though the organic and fair trade labels refer to very different attributes [69].

\section{Risks of partnerships}

The increased role of NGOs in society causes them to face up to their obligation to be worthy of the trust that is placed in them by providing evidence that they are funded independently and have transparent management. This is the first obstacle to joint work between NGOs and companies. Differences in perception, values, and interests between these two actors, unequal power in the relationship and the common risk of image are also other difficulties to overcome in the context of partnership [62]. Therefore, it is necessary to understand the potential risks to be able to limit them. The three main risks, specific to partnerships with a labeling scheme, are analyzed in the present paper: the new competition among NGOs, NGO capture by firms, and inconsistency in a partnership.

\subsection{Competition}

An NGO with a monopoly position on a specific issue or cause with a well-known label and existing partnerships with many companies becomes less interesting as a partner for firms from a profit-maximizing perspective because this powerful market position limits the ability of its label to differentiate between the products of potential new partner companies and thereby limits the NGO's attractiveness as a label supplier for them. Competition between NGOs is thus necessary, and one can observe that the market for NGOs' services has led to an increasing number of NGOs. 
However, the competition among NGOs to develop partnerships with companies creates a risk linked to the proliferation of NGOs. The authors of [48] indicate that the entry of NGOs into the label market generates more intense competition among labels and thereby leads to a reduction in their stringency. Facing competition, NGOs may be tempted to moderate their requirements to attract corporations or to conclude partnerships. Another theoretical work also shows that competition among NGOs leads to a decrease in the most stringent standard but positively produces an increase in overall impact [49]. These works highlight the trade-off between quality and quantity faced by NGOs. In other words, NGOs are caught between the stringency of the required standards accepted by firms wanting to build a partnership with them and the number of firms attracted to their mission. The overall social impact may be intensified either by the level of requirement in the mission statements or the number of firms with the quantity of products sold, as there is an inverse relationship between these two factors.

Fair trade labeling schemes are a good illustration of the competition among NGOs. The FLO recently proposed the development of a Fairtrade Sourcing Partnership (FSP) with a new fair trade label. Currently, for a product to bear the Fairtrade logo, FLO standards require that all ingredients that can be certified must be and that a minimum of $20 \%$ of the total product comprise Fairtrade certified ingredients. The FSP would shift from this policy and use a new logo to certify products containing only one certified ingredient-sugar, cocoa, or cotton—even if the ingredient composes less than $20 \%$ of the total product. This new scheme aims to increase the volume of commodities being purchased from Fairtrade certified farmers and to engage companies that do not want to commit to the full cost of certifying their products or that are only interested in particular commodities. Nine companies, including Mars, Rewe, and Lidl, signed up for FSP cocoa when it launched in 2014. According to organizations such as Oxfam, the development of the FSP is explained by the decline of market share of the Fairtrade label due to the competition with other labels, such as Rainforest Alliance and UTZ Certified. Indeed, they have grown more rapidly than the Fairtrade label, exceeding it in terms of sales volume [70]. The introduction of new certification marks has contributed to consumer confusion and possibly the erosion of credibility. Moreover, new marks/logos have less stringent standards for fair trade products and are less costly for companies to adopt, leading to a high risk that the marks will devalue the Fairtrade label or become new references for fair trade on the market. By the way, after the success of the FSP program with specific products in some countries, Fairtrade is seeking to extend the program to all other products with the new Fairtrade Sourced Ingredient (FSI) model.

With their inductive analysis on "nonstate market-driven" governance systems, Bernstein and Cashore explain that with sector-specific labels, in a first step, strict standards are adopted by a small number of firms in an industry, creating niche markets and, in a second step, to attract most mainstream firms, standards setters must relax their requirements [71]. This seems to be well illustrated in the case of the fishery sector. Due to the perceived failure of international and national law to control fishing behavior, the governance of fisheries has been increasingly conducted through voluntary sustainability labels and related certification systems. NGOs have been the front-runners in developing ecolabeling schemes in this sector, with two main international fisheries certification programs, the Marine Stewardship Council (MSC), established by the WWF and Unilever in 1997, but independent of them since 1999, and the Friend of the Sea (FOS), created in 2005 in Europe by the NGO the Earth Island Institute [72]. The first actor, the MSC, has relatively more stringent standards and stricter compliance methods and is more inclusive in relation to the FOS [72,73].

\subsection{Capture}

An NGO may lose credibility and legitimacy among consumers or citizens, corporations, and other organizations if the NGO's partner experiences a scandal linked to information revelation. This spillover is more likely when the partnership is materialized through an NGO-certified label on products that connects the name of the NGO with the firm's brand. Moreover, an NGO needs corporations to implement standards to achieve its objectives and, ultimately, to exist. Thus, these 
labeling strategies are riskier for NGOs in terms of dependency on businesses. This idea concerns a central point of the partnership: the exchange of information and the risk of information manipulation on behalf of firms, as information is the strategic input in the partnership. I call this "NGO capture", which is analogous to "regulatory capture". The theory of regulatory capture states that interest groups, such as industry members, have the means to influence public decision makers and will try to capture these decisions to their advantage because of information asymmetry [74]. In our context, a corporation may "capture" an NGO by dominating it through a partnership, that is, a contract, with distorted information. In such a scenario, a firm reveals positive information about its environmental or social performance to an NGO while hiding negative information on these or other dimensions. This situation puts the NGO in an awkward position. This idea of "NGO capture" may be related to that of the "co-opted NGO". Baur and Schmitz define co-optation as the ability of a corporation to "bring the interests of a challenging group into alignment with its own goals" [75]. Co-optation results in the loss of NGO autonomy. However, the alignment between firms' and NGOs' interests through partnerships can create a capture of the NGO only through information asymmetry in favor of firms as well as through information manipulation or withholding information.

An illustrative example of this risk is the change in the partnership between Fairtrade and Mondelēz. In 2016, Cadbury, a British multinational confectionery brand owned by Mondelēz International, pulled out of the Fairtrade labeling scheme, replacing it with the Mondelēz-owned Cocoa Life program created in 2012. However, the Fairtrade logo appears on the reverse of Cadbury's Cocoa Life-marked bars because although the product no longer follows Fairtrade standards, the Cocoa Life program is verified by FLO-Cert, the global certifier for Fairtrade. There seems to be substantial differences between the independent Fairtrade label and the Mondelez-owned program, such as the minimum guaranteed price for producers in fair trade criteria; however, neither Fairtrade nor Mondelēz has published a comparison of the two labeling schemes. Other MNCs, such as Nestlé with its Cocoa Plan launched in 2009, have developed their own sustainable sourcing schemes after working with NGOs. Sloane Hamilton, a labor rights policy advisor at Oxfam, said that "standards measuring environmental and social issues need to be transparent because, once this process happens behind closed doors, it is difficult to see how companies and farms apply them" [76].

NGOs face the challenge of maintaining independence and avoiding manipulation, as independence is a core credential and a sign of legitimacy. The primary factors that protect NGOs from being captured by businesses are evaluation mechanisms with external audits, such as certification and accreditation, and relationships with other business partners to prevent financial dependence. Moreover, NGOs should protect themselves against the risk of "NGO capture" through a contractual commitment defining the partnership: any information disclosure affecting the purpose of the partnership could induce a breach of the partnership. Independence is also in the best interest of NGOs' corporate partners because it is crucial for the long-term credibility of the partnership [75]. The risk of capture and greenwashing seem greater when the level of commitment between partners is at the transactional stage due to the low exchange of information when the synergies between both entities are not strong. Moreover, in an integrative or transformational stage, there are generally greater reciprocal information flow, transparency, trust, and interdependency in the project, which might reduce the risk of capture. In 2008, Unilever decided to work with its suppliers and with the Rainforest Alliance to certify new cocoa farmers in West Africa [77]. An example of a long-term partnership is that, currently, over 98\% of Magnum cocoa beans are sustainably sourced from Rainforest Alliance Certified producers. Moreover, the Ben \& Jerry's case is a good example of the transformational stage and of how when there is mission congruency, the probability of NGO capture appears to be low.

\subsection{Inconsistency}

As partners' reputation and legitimacy may increase through cooperation, partners may lose reputation if an inconsistency appears in the purpose of the partnership or in the association of the two partners. These two elements must make sense at all levels-product, brand, company, association 
with the NGO_-and for all other stakeholders. Dissonances are quickly perceptible and undermine credibility.

For instance, the partnership between the WWF and Coca-Cola aims to conserve water resources and to replace the water that is used to produce drinks sold by the company, i.e., "global water neutrality". However, many analysts label this partnership greenwashing because the term "water neutrality" is not scientifically defined and because Coca-Cola still faces problems in misusing water resources. This controversy affects the WWF, which stands accused by some media of being "too dependent on corporate cash to campaign objectively, too close to companies to challenge the business-as-usual orthodoxy" [78]. This scandal may tarnish an NGO's other corporate partners. For instance, how can a company such as Rainett, a partner of the WWF since 1999 and the pioneering brand of ecological cleaning products thanks to Ecolabel certified ranges, react?

In addition, an inconsistency in the image of the partnership can lead to failure. In this way, Kraft has been working with the Rainforest Alliance since 2003 to create, among other things, a new coffee in France under the Jacques Vabre brand, "un café pour agir" (a coffee for action). Under the terms of the agreement, Kraft funds the technical assistance and training required to improve living and working conditions on coffee farms, purchases significant and increasing quantities of certified sustainable coffee to blend into its mainstream European brands, and stimulates consumer demand in Western European and US markets through the introduction of $100 \%$ certified products under existing trademarks. The product "un café pour agir" was nevertheless a commercial failure in France for two reasons. First, Rainforest Alliance was not known in France at the time; the label bears no significance to consumers. Second, the name of the product, which was very militant, was far from the brand's roots. Currently, Kraft sells several products of the Jacques Vabre brand with the Rainforest Alliance logo, without a particular product name.

To protect themselves against such risks, NGOs must maintain consistency in their messaging and actions and must carefully choose partners with which they can work for long periods of time, even after a commercial failure.

\section{Conclusion}

Partnerships between businesses and NGOs in the pursuit of CSR through voluntary product labeling schemes have become increasingly prevalent in recent years. This article studies these collaborative relationships based on economic and management concepts and streams of literature and includes numerous examples. The aim is to provide some theoretical explanations for such developments, with the main conclusion being that the drivers and risks of both partners converge and mix.

While companies and NGOs are generally seen as pursuing different objectives, this study shows a convergence of their drivers because each partner enters the other's sphere. Indeed, a corporate-NGO partnership represents a good opportunity for firms to learn in the emerging field of CSR, and it can be a tool to more closely connect CSR and economic performance [61]. Additionally, from the NGOs' point of view, it represents a way to better understand the business sector at all levels including governance, activities, and the business impacts on other stakeholders. Moreover, a successful collaboration can create spillover for new forms of partnerships and can contribute to a more efficient allocation of resources for the common good [62] and to the dissemination of innovative knowledge as a public good [43]. Further, one can observe organizations born of civil society initiatives with a common good objective. Given their motivations and objectives, they have an incentive to work with large, consumer-oriented, well-known companies to obtain visibility and viability. They are then transformed and adopt the methods and functioning of these MNCs. These NGOs have clients, and they are inspired by the methodologies of consulting firms and the operations of MNCs, and they thereby become business-like [79]. As is often the case with companies or consulting firms, they communicate little if anything about the services they perform for the sake of confidentiality. These corporate-NGO partnerships thus introduce a market-driven logic into the nonprofit sector. On the corporate side, 
these partnerships are changing the positioning of companies and blurring existing boundaries. In recent years, some MNCs have decided to give impetus to CSR by joining forces with NGOs to promote sustainable development and CSR in their sector or country. For instance, since the turn of the century, roundtables have been created to gather the main private actors in a global commodity chain and social and environmental NGOs to make the entire commodity chain more sustainable, often through a labeling scheme. A roundtable on sustainable palm oil, an initiative of Unilever and the WWF, is regarded as the one that set the trend for the initiation of roundtables in other commodity chains.

In the context of sustainable development, the previously well-defined boundaries between companies and NGOs are blurred, thus allowing the expression of new identities that carry solutions through a new way of conceiving of both the company and the NGO. The existence of shared goals and the complementarity of resources, mainly information and legitimacy, are the basis for a successful partnership.

If the roles and the motives of each partner mix, then the risks also mix. The concessions made by some corporations to develop partnerships with some NGOs may be unreasonable for other stakeholders, such as shareholders. The risk is then the lack of financial assets. Moreover, launching CSR activities in a noncredible manner bears a risk of business losses or of accusations of greenwashing. For corporations, such accusations may destroy their reputation and legitimacy, affect their production activities, and decrease their profits for a certain period of time. Greenwashing accusations may also spill over to the NGOs involved with such corporations, affecting their credibility and legitimacy while generating a loss of confidence by many society members - the primary capital of NGOs. This risk is intensified because the partnership materializes through a brand's association with an NGO label for specific firm products. This argument is related to the risk of dependence. Indeed, partnerships may be problematic because they create resource dependence for NGOs, compromising their ability to challenge firm behavior. Indeed, the resource dependence perspective asserts that one consequence of competition and the sharing of scarce resources is some degree of dependence of NGOs on businesses. This dependence also induces the risk of "NGO capture" by businesses due to information asymmetry between partners because the main input in the relationship is information; through labels and certifications, NGOs summarize the information that firms reveal to them directly or indirectly through the certification process. This can result in a loss of trust in the nonprofit sector along with a loss of identity for NGOs, essentially turning NGOs into consulting firms. Moreover, in this context of partnerships, like firms, NGOs bear the risks related to the competitive market, specifically, direct competition, commercial failure, and lack of profitability. To limit the risks related to corporate-NGO partnerships, NGOs must try to differentiate themselves by focusing on specific and well-defined issues. By collaborating with several firms from different sectors on specific issues, NGOs avoid direct competition and remain independent from the corporations with which they work.

Future research should investigate empirical evidence of the risk of "NGO capture", especially by focusing on case studies with information exchange analysis. Future research should also focus on variation in the corporate side while accounting for the differences among NGO partners and their strategies. In economics, it might be interesting to develop theoretical studies about NGOs' objectives to better forecast their behaviors and the relationships with the agents with whom they interact, such as consumers, firms, governments, and other NGOs. Moreover, as the role of NGOs is continuously growing, questions of their accountability and legitimacy become more relevant and should require consideration in theoretical analyses.

Funding: This research was funded by a French State fund managed by the Agence Nationale de la Recherche under the grant number ANR-11-ALID0002, OCAD. The support of the Chair for Sustainable Finance and Responsible Investment (Toulouse-IDEI and Ecole Polytechnique) is gratefully acknowledged.

Acknowledgments: I would like to thank Jean-Pierre Ponssard and Vanina D. Forget for their helpful comments on an earlier version of this paper.

Conflicts of Interest: The author declares no conflict of interest. 


\section{References}

1. Utting, P. Regulating business through multistakeholder initiatives: A preliminary assessment. In Voluntary Approaches to Corporate Responsibility: Readings and a Resource Guide. NGLS/UNRISD Eds.; NGLS Development Dossier. United Nations, Geneva, 2002.

2. 2018 Edelman Trust Barometer. Available online: https://www.edelman.com/trust-barometer/ (accessed on 19 July 2018).

3. Baur, D.; Palazzo, G. The moral legitimacy of NGOs as partners of corporations. Bus. Ethics Q. 2011, 21(4), 579-604.

4. Mirvis, P.; Herrera, M. E. B.; Googins, B.; Albareda, L. Corporate social innovation: How firms learn to innovate for the greater good. J. Bus. Res. 2016, 69(11), 5014-5021.

5. Baron, D. P. Private politics, corporate social responsibility, and integrated strategy. J. Econ. Manage. Strat. 2001, 10(1), 7-45.

6. Bénabou, R.; Tirole, J. Individual and corporate social responsibility. Economica 2010, 77(305), 1-19.

7. De Boer, J. Sustainability labelling schemes: the logic of their claims and their functions for stakeholders. Bus. Strateg. Environ. 2003, 12(4), 254-264.

8. Loconto, A.; Busch, L. Standards, techno-economic networks, and playing fields: Performing the global market economy. Rev. Int. Polit. Econ. 2010, 17(3), 507-536.

9. Ibanez, L.; ECOLABELS: Are They Environmental-Friendly?. In Encyclopedia of Law and Economics; Marciano A., Battista Ramello G. Eds.; Springer, New York, NY, 2016; pp. 1-9.

10. Big Room Inc and World Resource Institute. 2010 global ecolabel monitor. Ecolabelindex.com. Retrieved from http:/ /www.ecolabelindex.com/downloads/Global_Ecolabel_Monitor2010.pdf

11. Margolis, J. D.; Walsh, J. P. Misery loves companies: Rethinking social initiatives by business. Admin. Sci. Quart. 2003, 48(2), 268-305.

12. Selsky, J. W.; Parker, B. Cross-sector partnerships to address social issues: Challenges to theory and practice. J. Manage. 2005, 31(6), 849-873.

13. Yaziji, M.; Doh, J. NGOs and corporations: Conflict and collaboration. Cambridge University Press, New York, USA, 2009.

14. Kourula, A.; Laasonen, S. Nongovernmental organizations in business and society, management, and international business research: Review and implications from 1998 to 2007. Bus. Soc. 2010, 49(1), 35-67.

15. Porter, M. E.; Kramer, M. R. Creating Shared Value. Harvard Bus. Rev. 2011, 89(1/2), 62-77.

16. Austin, J. E.; Seitanidi, M. M. Collaborative value creation: A review of partnering between nonprofits and businesses: Part I. Value creation spectrum and collaboration stages. Nonprof. Volunt. Sector Q. 2012, 41(5), 726-758.

17. Seitanidi, M. M.; Crane, A. Implementing CSR through partnerships: Understanding the selection, design and institutionalisation of nonprofit-business partnerships. J. Bus. Ethics 2009, 85(2), 413-42.

18. Crifo, P.; Sinclair-Desgagné, B. The economics of corporate environmental responsibility. Int. Rev. Environ. Resour. Econ. 2014, 7(3-4), 279-297.

19. Crifo, P.; Forget, V. D. The economics of corporate social responsibility: A firm-level perspective survey. J. Econ. Surv. 2015, 29(1), 112-130.

20. Kitzmueller, M.; Shimshack, J. Economic perspectives on corporate social responsibility. J. Econ. Lit. 2012, 50(1), 51-84.

21. Schmitz, J.; Schrader, J. Corporate social responsibility: A microeconomic review of the literature. J. Econ. Surv. 2015, 29(1), 27-45.

22. Garriga, E.; Melé, D. Corporate social responsibility theories: Mapping the territory. J. Bus. Ethics 2004, 53(1-2), 51-71.

23. Aguinis, H.; Glavas, A. What we know and don't know about corporate social responsibility: A review and research agenda. J. Manage. 2012 38(4), 932-968.

24. Burchell, J.; Cook, J. Sleeping with the enemy? Strategic transformations in business-NGO relationships through stakeholder dialogue. J. Bus. Ethics 2013, 113(3), 505-518.

25. Laasonen, S.; Fougère, M.; Kourula, A. Dominant articulations in academic business and society discourse on NGO-business relations: A critical assessment. J. Bus. Ethics 2012, 109(4), 521-545. 
26. Lantos, G. P. The Boundaries of Strategic Corporate Social Responsibility. J. Consum. Mark. 2001, 18(7), 595-632.

27. Lepoutre, J.; Dentchev, N. A.; Heene, A. Dealing with uncertainties when governing CSR policies. J. Bus. Ethics 2007, 73(4), 391-408.

28. Nelson, P. Information and Consumer Behaviour. J. Polit. Econ. 1970, 78(2), 311-329.

29. Darby, M. R.; Karni, E. Free competition and the optimal amount of fraud. J. Law Econ. 1973, 16(1), 67-88.

30. Hardin, G. The Tragedy of the Commons. Science 1968, 162(3859), 1243-1248.

31. Arrow, K. J. Essays in the Theory of Risk Bearing. Markham Pub. Co, Chicago, 1970.

32. Akerlof, G. A. The Market for "Lemons": Quality Uncertainty and the Market Mechanism.Q. J. Econ. 1970 84(3), 488-500.

33. Caswell, J. A.; Mojduszka, E. M. Using informational labeling to influence the market for quality in food products. Am. J. Agr. Econ. 1996, 78(5), 1248-1253.

34. Lyon, T. P. Good Cop/Bad Cop: Environmental NGOs and Their Strategies. Resources For the Future Press, Washington DC, London, 2010.

35. Maxwell, J. W. An Economic Perspective on NGO Strategies and Objectives. In Good op/Bad Cop: Environmental NGOs and their Strategies towards Business; Lyon T. P. Eds. Resources for the Future Press, Washington DC, London, 2009; pp. 136-163.

36. Baron, D. P. The Industrial Organization of Private Politics. Q. J. Polit. Sci. 2012, 7(2), 135-174.

37. Vogel D. The Market for Virtue - The Potential and Limits of Corporate Social Responsibility. Brookings Institution Press, Washington, USA, 2005.

38. Elkington, J.; Beloe, S. The Twenty-First-Century NGO. In Good Cop/Bad Cop Environmental NGOs and their strategies toward business; Lyon T.P., Eds. Resources For the Future Press, Washington DC, London, 2010; pp. 17-47.

39. Suchman, M. C. Managing legitimacy: Strategic and institutional approaches. Acad. Manage. Rev. 1995, 20(3), 571-610.

40. Porter, M. E.; Kramer, M. R. Strategy and society: The link between competitive advantage and Corporate Social Responsibility. Harvard Bus. Rev. 2006, 84(12), 78-92.

41. Freeman, R.E. Strategic Management: A stakeholder Approach. Boston, MA: Pitman, 1984.

42. Arenas, D.; Lozano, J. M.; Albareda, L. The role of NGOs in CSR: Mutual perceptions among stakeholders. J. Bus. Ethics 2009, 88(1), 175-197.

43. Yan, X.; Lin, H.; Clarke, A. Cross-Sector Social Partnerships for Social Change: The Roles of Non-Governmental Organizations. Sustainability 2018, 10(2), 558.

44. Schepers, D. H. Challenges to legitimacy at the Forest Stewardship Council. J. Bus. Ethics 2010, 92(2), $279-290$.

45. Poret, S. Mainstreaming Fair Trade: A Discussion Through the Lipton Tea Case. In Corporate social responsibility: from compliance to opportunity? Crifo, P., Ponssard, J.-P. Eds.; Editions de l'Ecole Polytechnique: Palaiseau, France, 2010; pp. 189-206.

46. Brinckerhoff, P. C. Mission-based management: Leading your not-for-profit in the 21st century (Vol. 231). John Wiley \& Sons, 2009.

47. Heyes, A.; Martin, S. NGO mission design. J. Econ. Behav. Organ. 2015, 119, 197-210.

48. Heyes, A.; Martin, S. Social labeling by competing NGOs: A model with multiple issues and entry. Manage. Sci. 2017, 63(6), 1800-1813.

49. Poret, S. Label Battles: Competition among NGOs as Standard Setters. J. Econ. Behav. Organ. 2019, 160, 1-18.

50. Heyes, A. G.; Maxwell, J. W. Private vs. public regulation: political economy of the international environment. J. Environ. Econ. Manage. 2004, 48(2), 978-996.

51. Bottega, L.; De Freitas, J. (2009). Public, private and nonprofit regulation for environmental quality. J. Econ. Manage. Strat. 2009, 18(1), 105-123.

52. Fischer, C.; Lyon, T. P. Competing environmental labels. J. Econ. Manage. Strat. 2014, 23(3), 692-716.

53. Fischer, C.;T.P. Lyon. A theory of multi-tier ecolabel competition. J. Assoc. Environ. Resour. Economists forthcoming.

54. Bhattacharya, C. B.; Sen, S. Doing better at doing good: When, why, and how consumers respond to corporate social initiatives. Calif. Manage. Rev. 2004, 47(1), 9-24.

55. Austin, J. E.; Seitanidi, M. M. Collaborative value creation: A review of partnering between nonprofits and businesses. Part 2: Partnership processes and outcomes. Nonprof. Volunt. Sector Q. 2012, 41(6), 929-968. 
56. Dammert, A. C.; Mohan, S. A Survey of the Economics of Fair Trade. J Econ. Surv. 2015, 29(5), 855-868.

57. Tully, S. M.; Winer, R. S. The role of the beneficiary in willingness to pay for socially responsible products: a meta-analysis. J. Retailing 2014, 90(2), 255-274.

58. Rode, J.; Hogarth, R. M.; Le Menestrel, M. Ethical differentiation and market behavior: An experimental approach. J. Econ. Behav. Organ. 2008, 66(2), 265-280.

59. Etilé, F.; Teyssier, S. Signaling Corporate Social Responsibility: Third-Party Certification versus Brands. Scand. J. Econ. 2016, 118(3), 397-432.

60. Feicht, R.; Grimm, V.; Seebauer, M. An experimental study of corporate social responsibility through charitable giving in Bertrand markets. J. Econ. Behav. Organ. 2016, 124, 88-101.

61. Arya, B.; Salk, J. E. Cross-sector alliance learning and effectiveness of voluntary codes of corporate social responsibility. Bus. Ethics Q. 2006, 16(2), 211-234.

62. Jamali, D.; Keshishian, T. Uneasy alliances: Lessons learned from partnerships between businesses and NGOs in the context of CSR. J. Bus. Ethics 2009, 84(2), 277-295.

63. Jonker, J.; Nijhof. A. Looking through the Eyes of Others: Assessing Mutual Expectations and Experiences in Order to Shape Dialogue and Collaboration between Business and NGOs with Respect to CSR. Corp. Gov. 2006, 14(5), 456-66.

64. Samii, R.; Van Wassenhove, L. N; Bhattacharya, S. An Innovative Public-Private Partnership: New Approach to Development. World Dev. 2002, 30(6), 991-1008.

65. Reinecke, J.; Manning, S.; Von Hagen, O. The emergence of a standards market: Multiplicity of sustainability standards in the global coffee industry. Organ. Stud. 2012, 33(5-6), 791-814.

66. Austin, J. E. Strategic Collaboration Between Nonprofits and Business. Nonprof. Volunt. Sector Q. 2000, 29(1), 69-97.

67. Mirvis, P.; Googins, B. Stages of corporate citizenship. Calif. Manage. Rev. 2006, 48(2), 104-126.

68. Etilé, F.; Teyssier, S. Corporate Social Responsibility and the Economics of Consumer Social Responsibility. Rev. Agri. Environ. Stud. 2013, 2, 221-259.

69. Tagbata, D.; Siriex, L. Measuring consumer's willingness to pay for organic and fair trade products. Int. J. Consum. Stud. 2008, 32(5), 479-490.

70. Potts, J.; Lynch, M.; Wilkings, A.; Huppé, G. A.; Cunningham, M.; Voora, V. A. The state of sustainability initiatives review 2014: Standards and the green economy. Winnipeg, MB: International Institute for Sustainable Development, 2014.

71. Bernstein, S.; Cashore, B. Can non-state global governance be legitimate? An analytical framework. Regul. Gov. 2007, 1(4), 347-371.

72. Washington, S.; Ababouch, L. Private standards and certification in fisheries and aquaculture: current practice and emerging issues. FAO Fisheries and Aquaculture Technical Paper. No. 553. Rome, FAO, 2011.

73. Kalfagianni, A.; Pattberg, P. Fishing in Muddy Waters: Exploring the Conditions for Effective Governance of Fisheries and Aquaculture. Mar. Policy 2013, 38, 124-132.

74. Laffont, J. J.; Tirole, J. The politics of government decision-making: A theory of regulatory capture. Q. J. Econ. 1991, 106(4), 1089-1127.

75. Baur, D.; Schmitz, H. P. Corporations and NGOs: When accountability leads to co-optation. J. Bus. Ethics 2012, 106(1), 9-21.

76. Ionova, A. How fair is our food? Reuters, 2017.

77. Paschall, M.; Seville, D. Certified Cocoa: scaling up farmer participation in West Africa. Case Study Series, New Business Models for Sustainable Trading Relationships, 28, International Institute for Environment and Development/Sustainable Food Lab, 2012.

78. See the newspaper article from Guardian Professional on 15/10/2013, "WWF's president on business partnerships and greenwashing"

(http:/ / www.theguardian.com/sustainable-business/wwf-president-business-partnerships-greenwashing) and that from The Guardian on 4/12/2008, "Greenwash: Are Coke's green claims the real thing?" (http://www.theguardian.com/environment/2008/dec/04/coca-cola-coke-water-neutral).

79. Maier, F.; Meyer, M.; Steinbereithner, M. Nonprofit organizations becoming business-like: A systematic review. Nonprof. Volunt. Sector Q. 2016, 45(1), 64-86. 